\title{
Omeprazole for refractory gastroesophageal reflux disease during pregnancy and lactation
}

\author{
John K Marshall MD FRCPC, Alan BR Thomson MD PhD FRCPC FRCP FACG, David Armstrong MA MRCP(UK) FRCPC
}

\begin{abstract}
JK Marshall, ABR Thomson, D Armstrong. Omeprazole for refractory gastroesophageal reflux disease during pregnancy and lactation. Can J Gastroenterol 1998;12(3):225-227. Symptomatic gastroesophageal reflux is a common complication of pregnancy and lactation. However, the safety of many effective medical therapies, including oral proton pump inhibitors, has not been well defined. The administration of oral omeprazole to a 41year-old female during the third trimester of pregnancy, after ranitidine and cisapride failed to control her refractory gastroesophageal reflux, is reported. No adverse fetal effects were apparent, and the patient elected to continue omeprazole therapy $(20 \mathrm{mg} /$ day $)$ while breastfeeding. Peak omeprazole concentrations in breast milk ( $58 \mathrm{nM}, 3 \mathrm{~h}$ after ingestion) were less than $7 \%$ of the peak serum concentration ( $950 \mathrm{nM}$ at $4 \mathrm{~h}$ ), indicating minimal secretion. Although omeprazole is a potentially useful therapy for refractory gastroesophageal reflux during pregnancy and lactation, further data are needed to define better its safety and efficacy.
\end{abstract}

Key Words: Gastroesophageal reflux disease, Lactation, Omeprazole, Pregnancy, Proton pump inhibitors

\section{L'oméprazole pour le reflux gastro-œsophagien réfractaire durant la grossesse et l'allaitement}

RÉSUMÉ : Le reflux gastro-œsophagien symptomatique est une complication pendant la grossesse et l'allaitement. Or, l'innocuité de nombreuses thérapeutiques efficaces, y compris celle des inhibiteurs de la pompe à protons, n'a pas encore été clairement définie. On dresse ici le bilan d'un traitement oral à l'oméprazole chez une parturiente de 41 ans, au troisième trimestre de la grossesse, après l'échec de traitements à la ranitidine et au cisapride pour un reflux gastro-œsophagien réfractaire. Aucun effet indésirable n'a semblé affecter le fotus et la patiente a choisi de continuer son traitement à l'oméprazole $(20 \mathrm{mg} /$ jour $)$ pendant l'allaitement. Les concentrations de pointe d'oméprazole dans le lait maternel $(58 \mathrm{nM}$, 3 heures après son administration) équivalaient à moins de $7 \%$ des concentrations plasmatiques de pointe (950 nM après 4 heures), représentant une sécrétion minime dans le lait. L'oméprazole pourrait se révéler utile dans le traitement du reflux gastro-œsophagien réfractaire durant la grossesse et l'allaitement, mais il faudra accumuler d'autres données pour avoir une idée plus précise de son innocuité et de son efficacité.
$S_{c}^{v}$ ymptomatic gastroesophageal reflux disease (GERD) complicates $30 \%$ to $80 \%$ of all pregnancies. It is a common reason for physician consultation during pregnancy (1), but, in the majority of patients, reflux symptoms resolve rapidly after delivery (2). For many patients, lifestyle modification measures are effective, and oral antacids or alginates can be administered without significant risk to the developing fetus (3). Although few rigorous trials of antireflux therapies in pregnancy have been performed for ethical reasons, the available evidence supports the use of $\mathrm{H}_{2}$ receptor antagonists $\left(\mathrm{H}_{2} \mathrm{RA}\right)$ or sucralfate in selected patients $(1,3-7)$. In nonpregnant patients, proton pump inhibitors (PPIs) are significantly more effective than either prokinetic agents such as cisapride or $\mathrm{H}_{2} \mathrm{RAs}$, particularly for refractory GERD. There are, however, few data on their safety and efficacy during pregnancy and lactation. We report a patient who required therapy with oral omeprazole during the third trimester of pregnancy and postpartum without any apparent adverse effect, and present data on the excretion of omeprazole in breast milk.

\section{CASE PRESENTATION}

A 41-year-old primipara was referred to the gastroenterology service at 19 weeks of gestation because of worsening symptoms of gastroesophageal reflux refractory to treatment with an $\mathrm{H}_{2} \mathrm{RA}$ and a prokinetic agent. She first developed inter-

Division of Gastroenterology, McMaster University, Hamilton, Ontario; and Division of Gastroenterology, University of Alberta, Edmonton, Alberta

Correspondence: Dr David Armstrong, Division of Gastroenterology (HSC-4W8), McMaster University Medical Centre, 1200 Main Street

West, Hamilton, Ontario L8N 325. Telephone 905-521-2100 ext 3495, fax 905-521-4958, e-mail armstro@fhs.csu.mcmaster.ca

Received for publication December 8, 1997. Accepted March 13, 1998 


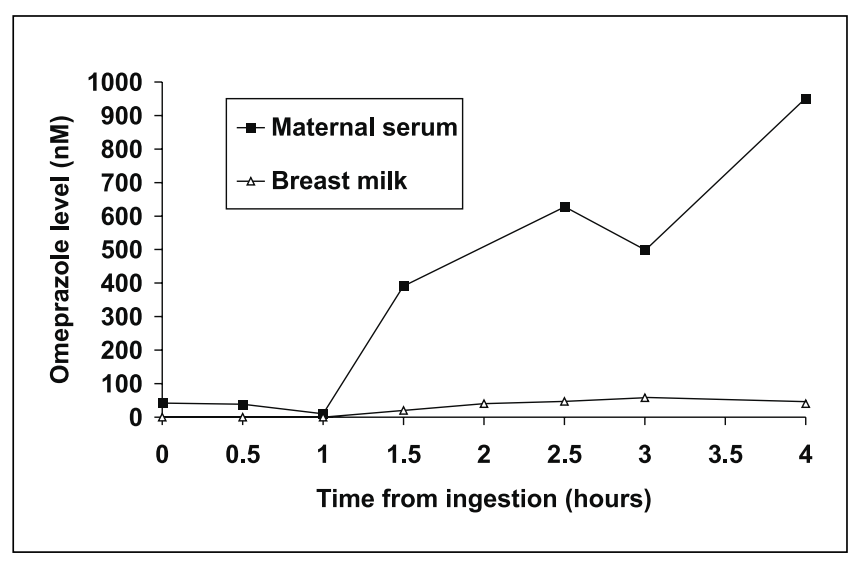

Figure 1) Omeprazole concentrations in maternal serum and breast milk up to $4 \mathrm{~h}$ after ingestion of a $20 \mathrm{mg}$ tablet

mittent nocturnal heartburn at the age of 26 years following an open cholecystectomy for cholelithiasis. There was no other medical history of note. Over the following 15 years, her symptoms were intermittent, requiring only occasional short courses of oral ranitidine. A gastroscopy at age 32 was unremarkable, and a barium meal revealed only a hiatus hernia.

Eight weeks after conception, the patient developed nocturnal heartburn, which became severe by the 12 th gestational week. A four-week course of oral ranitidine $(150 \mathrm{mg}$ every night) and a subsequent two-week course of cisapride (10 mg three times daily) produced no symptomatic relief. Gastroscopy, performed at 20 weeks because of worsening symptoms and frequent vomiting, revealed grade 2 esophagitis (8) and bile staining of the gastric mucosa. At 23 weeks, combination therapy with ranitidine $(150 \mathrm{mg}$ bid $)$ and cisapride (10 mg four times daily) was initiated because of refractory heartburn and nausea. However, her symptoms progressed and became intolerable by the 29th week, with continuous heartburn and nausea, and intractable vomiting. Monotherapy with omeprazole ( $20 \mathrm{mg}$ once daily) was then prescribed and produced significant symptomatic improvement, with only mild intermittent residual heartburn, minimal nausea and no vomiting. At 35 weeks' gestation, she was admitted to the obstetrical service for management of pregnancy-induced hypertension. In the 36th week, a healthy male child was delivered, requiring outlet forceps for fetal bradycardia. Apgar scores were 6 and 9 at 1 and 5 mins, respectively.

Postpartum, the patient elected to breastfeed her infant despite persistent severe reflux symptoms that necessitated ongoing administration of omeprazole (20 mg once daily). As a precaution, the patient fed the child just before taking her omeprazole dose at 08:00 h, then refrained from nursing for $4 \mathrm{~h}$ before expressing and discarding her breast milk at midday. The patient chose to wean her child at three months. Twelve months later she continues to take omeprazole as maintenance therapy, and both she and her child remain well.

Three weeks following the delivery, the patient consented to provide serial timed samples of blood and expressed breast milk for analysis. Baseline samples were collected at 08:00, then the remaining samples were collected at $30 \mathrm{~min}$ intervals over $4 \mathrm{~h}$ following ingestion of a single $20 \mathrm{mg}$ tablet of omeprazole. Blood samples were centrifuged immediately, and the separated serum stored at $-40^{\circ} \mathrm{C}$ along with the milk samples before shipment for laboratory analysis. Omeprazole concentrations in maternal serum and breast milk were determined with high performance liquid chromatography with a detection threshold of $10 \mathrm{nM}$ (9). The maternal serum concentration of omeprazole was negligible until 90 mins after ingestion and reached $950 \mathrm{nM}$ at 240 mins (Figure 1). The breast milk concentration of omeprazole began to rise 90 mins after ingestion but peaked after 180 mins at $58 \mathrm{nM}$, which was less than $7 \%$ of the highest serum level.

\section{DISCUSSION}

We report the successful use of omeprazole for treatment of refractory GERD during the third trimester of pregnancy and during lactation, without evidence of adverse effect to mother or child. Omeprazole was highly effective in a patient refractory to ranitidine and cisapride, both alone and in combination.

Considerable evidence supports the use of intravenous omeprazole before emergency caesarean section as prophylaxis against acid aspiration $(10,11)$. However, support for the safety of PPIs earlier in pregnancy remains largely anecdotal. The predominant concerns about the safety of PPIs in women of childbearing age relate to the possibility that therapy may affect the fetus, either directly by placental transfer of the PPI or indirectly because of the rise in maternal serum gastrin that accompanies reduced acid secretion. In the postpartum period, an additional concern is that omeprazole excreted in breast milk might be absorbed and produce significant inhibition of acid secretion in the infant.

Animal studies suggest that placental transfer may expose the fetus to plasma omeprazole levels of approximately one half those detected in the mother (12). However, it is not known whether omeprazole is teratogenic. Tsirigotis et al (13) reported two consecutive pregnancies resulting from in vitro fertilization in a woman who was taking oral omeprazole covertly at the time of each implantation. The first pregnancy was terminated when an ultrasound revealed anencephaly, and the second was terminated for severe talipes. Although the authors of that study urged caution in prescribing omeprazole in early pregnancy, several other case reports have documented ingestion of a PPI during the first trimester with no apparent adverse fetal effects (14-17). Similarly, no complications have been reported following the administration of omeprazole in the third trimester (1518 ), as was the case in our patient.

Although the potential long term trophic effects of gastrin are unknown, maternal and fetal serum gastrin levels are normally elevated during pregnancy $(19,20)$, and there have been no reports of untoward sequelae among children born to mothers with the Zollinger-Ellison syndrome (15). Furthermore, maternal gastrin may not cross the placenta (21).

Before receiving omeprazole, our patient received raniti- 
dine and cisapride without apparent ill effect, but also without any benefit. Relatively good evidence exists to support the safety of $\mathrm{H}_{2} \mathrm{RA}$ agents during pregnancy $(1,3,4,6,7)$. However, significant placental transfer of cisapride has been demonstrated in animal models, and cisapride is excreted in human breast milk $(22,23)$. Only a handful of case reports support the use of prokinetics such as cisapride and domperidone during pregnancy $(24,25)$.

The concentration of omeprazole in breast milk has not, to our knowledge, been reported previously. Because breast milk has a slightly lower $\mathrm{pH}$ than that of plasma, it might be anticipated that weak bases such as omeprazole would achieve higher concentration in breast milk. However, because omeprazole is highly protein-bound in plasma, it could be argued that only a small fraction is available for diffusion and that the actual concentration in breast milk is low (12). In support of the latter hypothesis, we demonstrated a peak concentration of omeprazole in expressed breast milk of $58 \mathrm{nM}, 3 \mathrm{~h}$ after ingestion of a $20 \mathrm{mg}$ tablet. This was less than one-10th the mother's peak plasma level. If a $5 \mathrm{~kg}$ infant were to consume $200 \mathrm{~mL}$ of breast milk per day, our data suggest that the maximum daily omeprazole ingestion would be $4.0 \mu \mathrm{g}$. This intake, equivalent to $0.80 \mu \mathrm{g} / \mathrm{kg}$ (omeprazole molecular weight 345.438 ), would be less than $1 \%$ of the usual adult dose of 200 to $400 \mu \mathrm{\mu g} / \mathrm{kg}$. Furthermore, omeprazole is unstable in an acid environment, with a half-life of

\section{REFERENCES}

1. Baron TH, Richter JE. Gastroesophageal reflux disease in pregnancy. Gastroenterol Clin North Am 1992;21:777-91.

2. Day JP, Richter JE. Medical and surgical conditions predisposing to gastroesophageal reflux disease. Gastroenterol Clin North Am 1990;19:587-607.

3. Lewis J, Weingold AB. The use of gastrointestinal drugs during pregnancy and lactation. Am J Gastroenterol 1985;80:912-23.

4. Magee LA, Inocencion G, Kamboj L, Rosetti F, Koren G. Safety of first trimester exposure to histamine $\mathrm{H}_{2}$ blockers: a prospective cohort study. Dig Dis Sci 1996;41:1145-9.

5. Ranchet $\mathrm{G}$, Gangemi O, Petrone M. [Sucralfate in the treatment of gravidic pyrosis.] G Ital Obstet Ginecol 1990;22:1-16.

6. Smallwood RA, Berlin RG, Castagnoli N, et al. Safety of acid-suppressing drugs. Dig Dis Sci 1995;40:63S-80S.

7. Larson JD, Patatanian E, Miner PB, Rayburn WR, Robinson MG. Double-blind placebo-controlled study of ranitidine for gastroesophageal reflux symptoms during pregnancy. Obstet Gynecol 1997;90:83-7.

8. Savary M, Miller G. The Oesophagus: Handbook and Atlas of Endoscopy. Solothurn: Verlag Gassmann AG, 1978.

9. Lagerstrom PO, Persson BA. Determination of omeprazole and metabolites in plasma and urine by liquid chromatography. J Chromatogr 1984;309:377-86.

10. Yau G, Kan AF, Gin T, Oh TE. A comparison of omeprazole and ranitidine for prophylaxis against aspiration pneumonitis in emergency cesarean section. Anaesthesia 1992;47:101-4.

11. Rocke DA, Rout CC, Gouws E. Intravenous administration of the proton pump inhibitor omeprazole reduces the risk of acid aspiration at emergency cesarean section. Anesth Analg 1994;1093-8

12. Ching MS, Morgan DJ, Mihaly GW, Hardy KJ, Smallwood RA. Placental transfer of omeprazole in maternal and fetal sheep. Dev Pharmacol Ther 1986;9:323-31.

13. Tsirigotis M, Yazdani N, Craft I. Potential effects of omeprazole in pregnancy. Hum Reprod 1995;10:2177-8.

14. Adamo S, Carrara M, Azzurro M, Aartori G, Vita G, Ghidini O. less than 10 mins at $\mathrm{pH}$ values below 4 (26). In the absence of the enteric coating used in oral formulations of omeprazole, the acid contents of the newborn infant's stomach would inactivate the small amount of omeprazole present in breast milk (27). Thus, it is expected that the omeprazole received by a breastfed infant would have a negligible effect on acid secretion.

\section{CONCLUSIONS}

This case report documents the successful use of oral omeprazole for refractory GERD during pregnancy and the absence of complications attributable to therapy with omeprazole, ranitidine and cisapride. It also demonstrates that there is minimal excretion of omeprazole in human breast milk during lactation. Because symptomatic GERD is a common and disabling complication of pregnancy, further studies are needed to assess the safety and efficacy profiles of PPIs in the management of GERD that has not responded to lifestyle modification, $\mathrm{H}_{2} \mathrm{RAs}$ and/or prokinetics.

ACKNOWLEDGEMENTS: The authors thank Dr B Brennan for her kind cooperation in allowing them to report this case, Mrs Cindy James for her invaluable help in collecting the samples and Dr Monika Keelan for her assistance in performing the omeprazole measurements.

Omeprazole treatment during first month of pregnancy: a case report. Ital J Gastroenterol 1993;25(Suppl 1):1. (Abst)

15. Harper MA, McVeigh JE, Thompson W, Ardill JES, Buchanan KD. Successful pregnancy in association with Zollinger-Ellison syndrome. Am J Obstet Gynecol 1995;173:863-4.

16. Woolfson K, Greenberg GR. Symptomatic improvement of gastroduodenal Crohn's disease with omeprazole. Can J Gastroenterol 1992;6:21-4.

17. Hollenz M. [Omeprazole during pregnancy: a case report]. TW Gynekol 1992;5:235-6.

18. Glasbrenner B, Swobodnik W, Malfertheiner P, Ditschuneit H. [Severe hyperemesis gravidarum - pathophysiological observations and new therapeutic approach]. Z Gastroenterol 1991;39:163-6.

19. Steen J, Westergaard L. Gastrin and gastrointestinal dyspepsia in pregnancy. Acta Obstet Gynecol Scand 1983;62:155-6.

20. Attia RR, Ebeid AM, Fischer JE, Goudsouzian NG. Maternal fetal and placental gastrin concentrations. Anaesthesia 1982;37:18-21.

21. Von Berger L, Henrichs I, Raptis S, et al. Gastrin concentration in plasma of the neonate at birth and after the first feeding. Pediatrics 1976;58:264-7.

22. Veereman-Wauters G, Monbaliu J, Meuldermans W, et al. Study of the placental transfer of cisapride in sheep: plasma levels in the pregnant ewe, the fetus, and the lamb. Drug Metab Dispos 1991;19:168-72.

23. Hofmeyr GJ, Sonnendecker EWW. Secretion of the gastrokinetic agent cisapride in human milk. Eur J Clin Pharmacol 1986;30:735-6.

24. Nishida S, Tanaka K, Kawaji H, Hamada N, Ono T, Taira A. [Ogilvie's syndrome in pregnancy: a case report]. Nippon Geka Gakkai Zasshi 1993;94:182-4.

25. Brock-Utne JG, Downing JW, Dimopoulos GE, Rubin J, Moshal MG. Effect of domperidone in lower esophageal sphincter tone in late pregnancy. Anesthesiology 1980;59:321-3.

26. Pilbrant A, Cederberg C. Development of an oral formulation of omeprazole. Scand J Gastroenterol Suppl 1985;30:113-20.

27. Euler AR, Byrne WJ, Meis PJ, Leake RD, Ament ME. Basal and pentagastrin-stimulated acid secretion in newborn human infants. Pediatr Res 1979;13:36-7. 


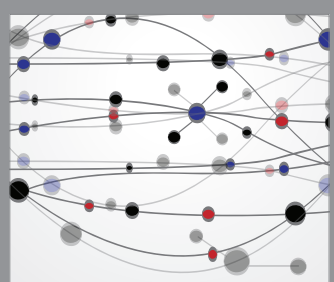

The Scientific World Journal
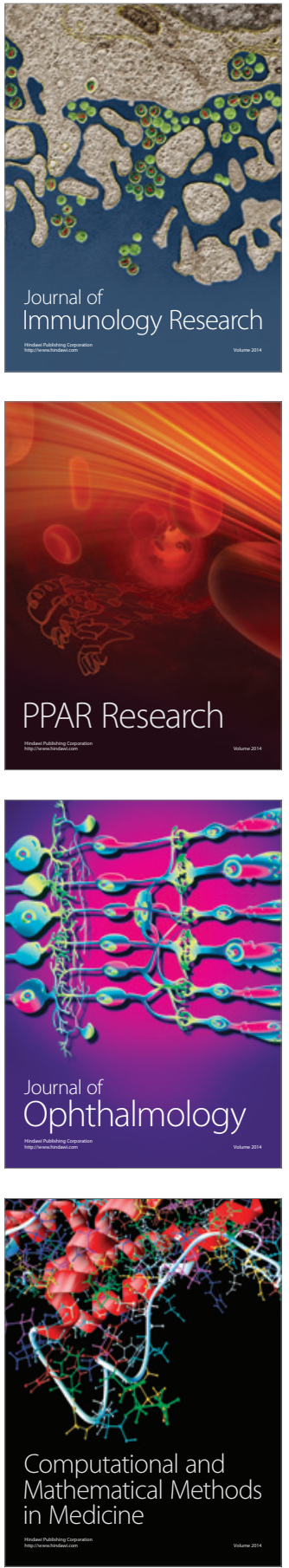

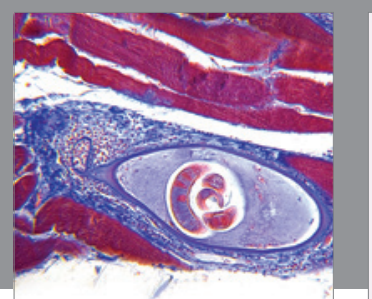

Gastroenterology Research and Practice

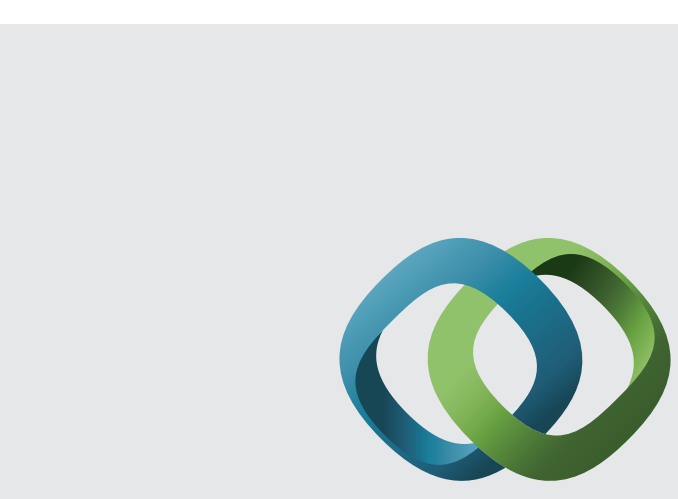

\section{Hindawi}

Submit your manuscripts at

http://www.hindawi.com
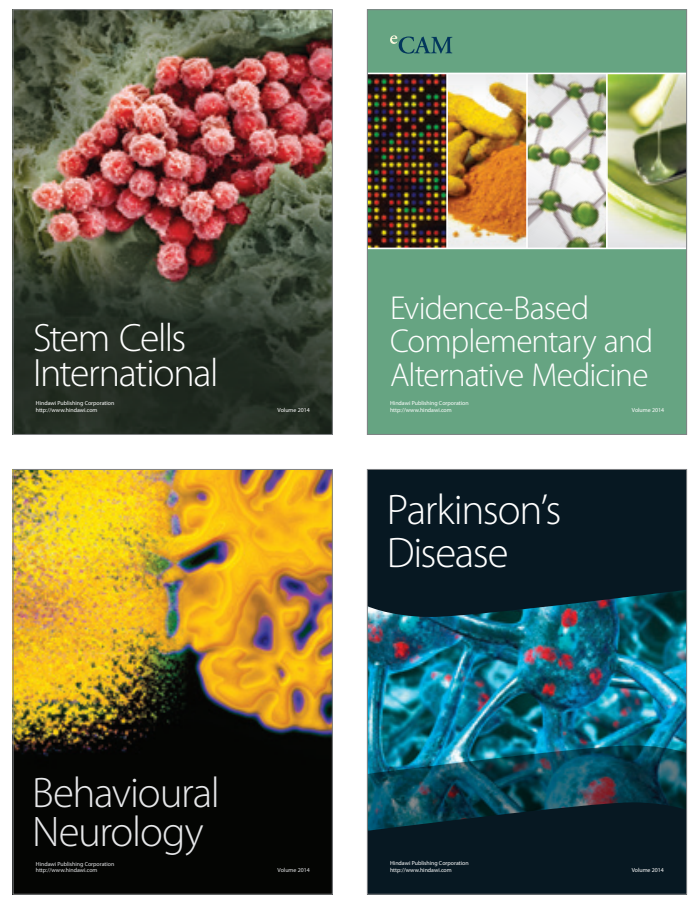
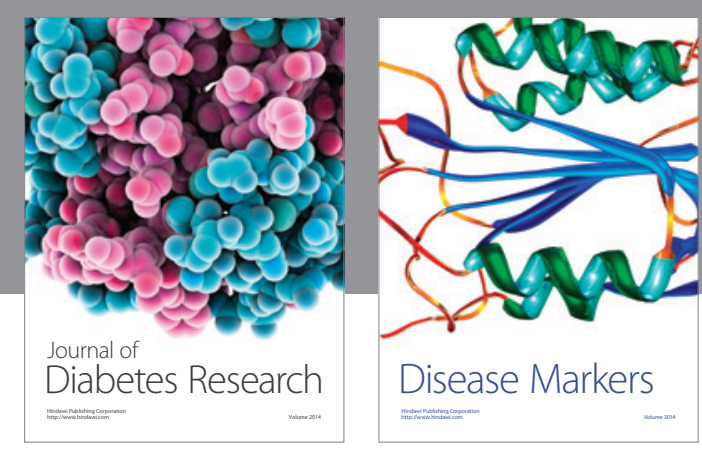

Disease Markers
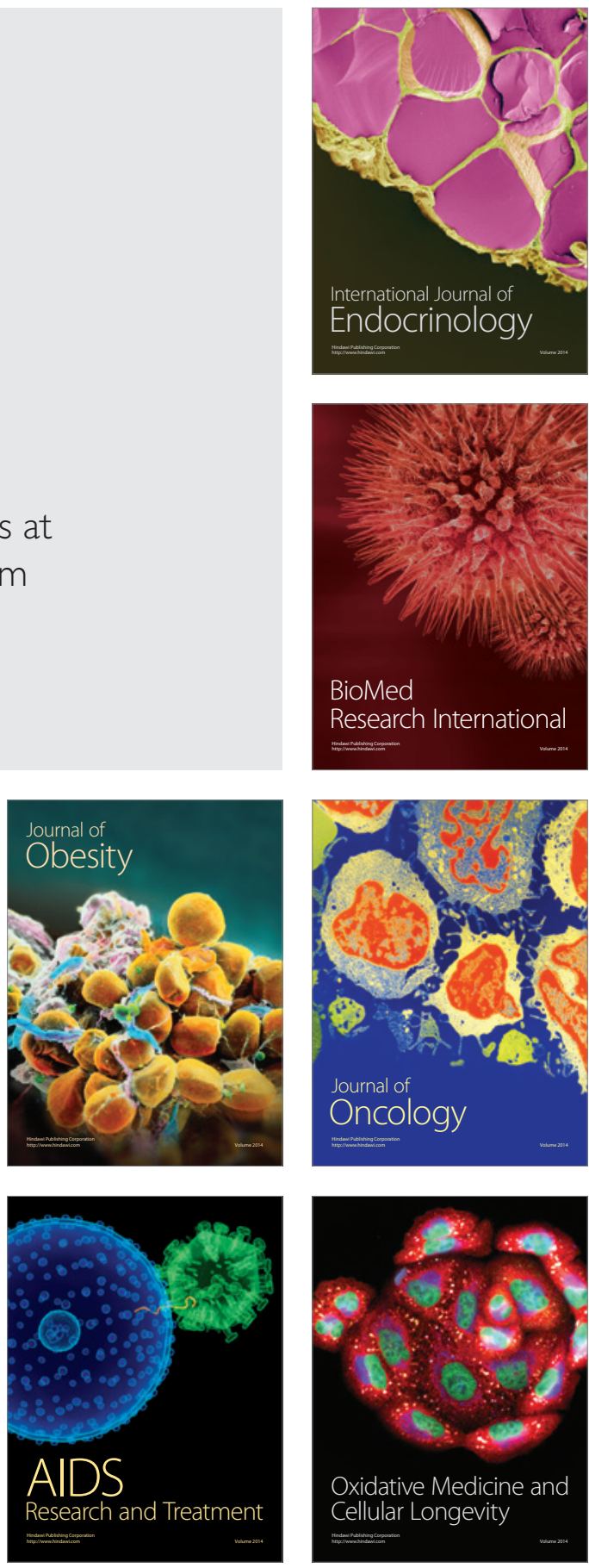